\title{
The Influence of Cooperative Learning Model of Think Pair Square with Problem Posing Task on Students' Mathematics Learning Outcome
}

\author{
Darsono \\ Universitas Negeri Surabaya \\ Surabaya, Indonesia \\ nurulasfufah123@gmail.com
}

\begin{abstract}
This study aims to look into the influence of coperative learning model of think pair share (TPS) with problem-posing task on students' learning outcomes as well as analyze the students' responses toward the learning model and the effectiveness of the learning model after the treatment on the topic of fraction. This research uses a pre-experimental study with one group pretest-posttest design to know the influence on student learning outcome, while a descriptive quantitative research methodology was employed to investigate the students' responses and effectiveness of the learning model. As many as 28 primary students at Surabaya were involved in the implementation of the learning model. Results of this study found that the use of cooperative learning model has an effect the students' learning outcomes, effectively improved the learning process, and lead student positively responded on the learning process and the learning aids used during the implementation
\end{abstract}

Keywords-cooperative learning, think pair share, problemposing

\section{INTRODUCTION}

Education has an important role in the life and progress of mankind. According to Slameto (2013:85), education is an effort organized, planned and ongoing retained earnings continuously throughout life to nurture students into a plenary, adult, and cultured. In Indonesia, education is regulated in a separate law on the National Education System (Sisdiknas)[14]

Adjie and Maulana (2006:17) state that mathematics is abstract for most elementary school students; thus it will make students difficult to learn mathematics if the teacher does not adjust to the students' thinking ability. In fact, elementary school students, in general, cannot think abstractly; therefore in learning mathematics, teacher must start learning mathematics from concrete to abstract.

To achieve of learning objects to the mathematics course, a teacher should be able to create conditions and learning situation that enable the student to actively shape, discover, and develop their knowledge. According Susanto (2015:190), it needs a variety of creative and strategic effort to realize the ideal goal of learning mathematics. On the other hand, there is also a need for a particular model, method or type of assessment that needs to be developed to assess or measure the achievement of the learning objective of mathematics.
Other problems related to visible learning is the lack of mastery of basic concepts and students' mathematical reasoning. Mathematics learning has not shown satisfactory results, most students still consider mathematics difficult, one of them is on fraction material.

Looking at the facts above, it is necessary to make improvements in learning so that student learning outcomes can increase. The effort to improve learning can certainly be realized through learning fun and meaningful. To overcome this problem, the researcher takes step by updating the learning model applied in the classroom. One of the learning model that can accommodate it is cooperative learning model of type Think, Pair, Square (PSG) with the problem-posing approach.

According to Anita lie (2010:58), the step in the cooperative learning model of the type of think pair square are: (1) the teacher divides the students into groups of four and assigns tasks to all groups, (2) students do and thinks about the task itself, (3) each student paired with one of the friends in the group and discussed with his/her spouse, (4) the two couples met again in the group of four and all the students got a chance to share their work in the group[13].

While the task-based learning of problem posing is a learning approach that requires students to prepare their own question or solving a question into more simple question that refers to the solution of the problem. According to Silver and Cai (2005:294) problem posing is the formulation of problems to relate the requirements on the questions that have been resolved in order to find other alternative solution [12].

\section{METHOD}

This study used an experimental method with design preexperiment one group pretest-posttest design without any comparison class. Thus, there was only one experiment group that was given pretest, treatment, and posttest. Besides, it also uses quantitative descriptive research methods to describe and analyze students' responses and the effectiveness of the application of learning model.

The population in this study are the students of SDN Dr. Sutomo IX, a primary school at Surabaya city, with the sample of research is the fourth grade consisting of 28 students. The research instrument used in this research are a test and nontest instrument. The test instruments in this research were written 
test of mathematics learning result. There were two stages of the given test, namely pretest and posttest. Non-test instruments were student activity observation sheets, teacher activity observation sheets in managing learning, and student response questionnaires sheet on learning.

The procedure in this research is shown in Figure 1:

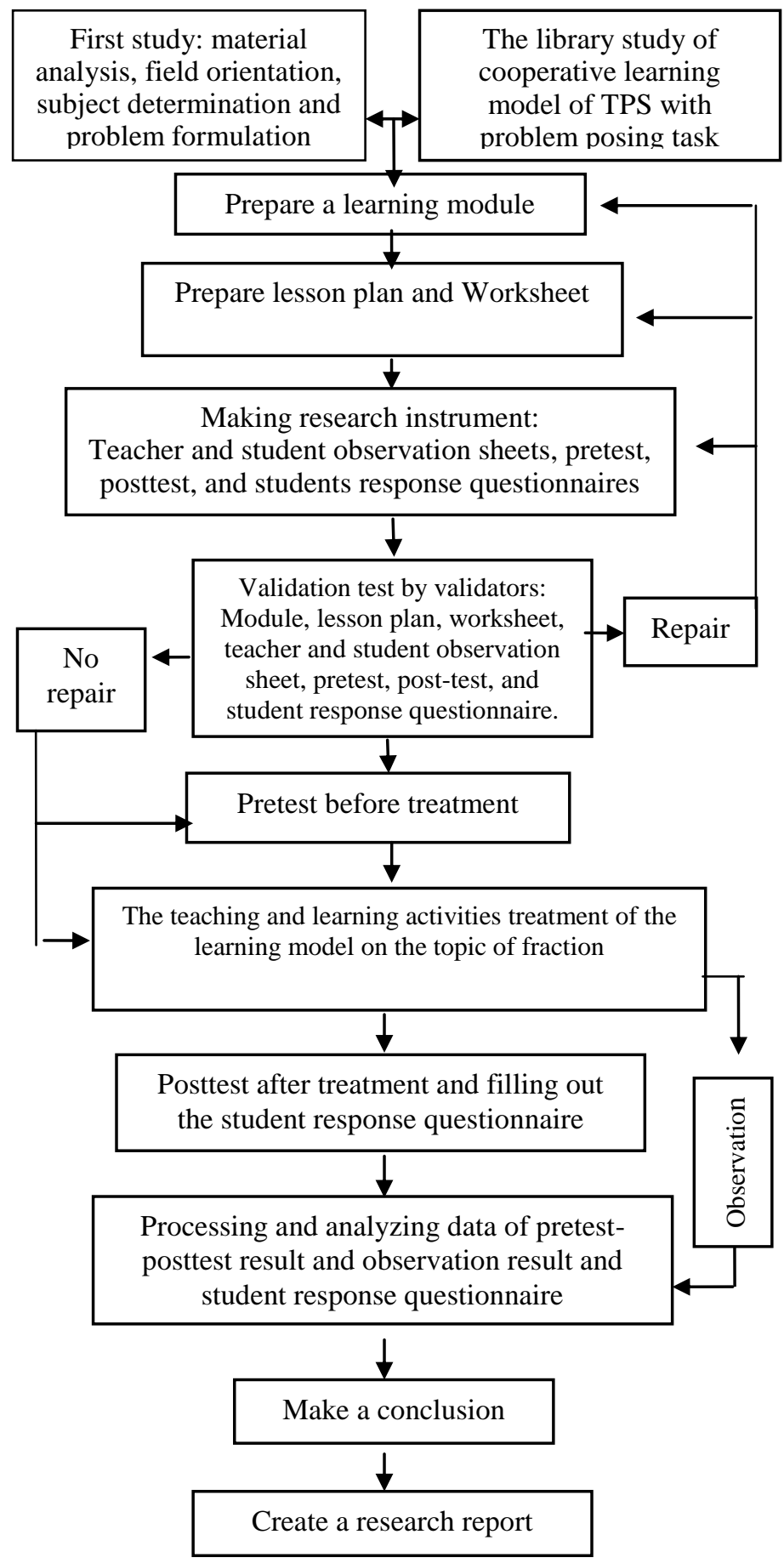

Figure 1. Research Procedure
The technique of data analysis: Expert assessment data for each learning device were analyzed by considering the feedback and suggestions from the validators. Through the analysis of quantitative descriptive data, it can be formulated whether the learning device can be used for the learning process or not.

The teacher and students observation sheets also are analyzed and assessed by the observer at the time of learning, so that observer will know the ability of teachers and student activity is good or not in applying the learning model. The ability of the teacher to manage to learn is said to be good if the average ability of teachers assessed to be in the category good or very good for all meetings. Meanwhile, students' activity is said to be active if the average score of students' activity is in the category active or very active for all meeting. The questionnaire of students' responses of the learning is said to be positive if the percentage of total student scores obtained on 'agree' or 'strongly agree' responses at least $80 \%$.

To analyze the learning result data the authors used uantitative data analysis technique from the result of pretest and posttest. The results of the data were used as the basis for hypothesis testing accepted or rejected [15]. As a prerequisite to determine the conclusion of the hypothesis test is accepted or rejected, the authors first conducted normality test using Chi-Square or X2 count on pretest data and post-test data and homogeneity test using formula of Fisher test ( $F$ test) from both data used by the researcher to know the sample of research come from the same population or not.

Furthermore, the test of research hypothesis was done based on the difference of learning result data, between pretest and posttest value.

\section{RESULTS AND DISCUSSION}

The final activity in this learning is the evaluation process used to know the learning outcomes that have been done. Hamalik (2012:30) states "learning outcomes is a change in behavior in students, which can be observed and measured in the form of changes in knowledge, attitude and skills". In this discussion, the authors discuss about the learning outcomes of the change of knowledge (cognitive) before being treated and after being treated with cooperative learning model of PSG type based on the task of problem posing on the topic of fraction.

Results of this study indicate that the learning model has effect on student learning outcomes. This is because the learning model is one of the learning methods that provide opportunities for the student to work independently and cooperate with others. The advantage of this technique is the optimization of student participation (Anita Lie, 2010:57).

Hypothesis test results can be explained as follows. After the preconditioning test, normality and homogeneity test is known that the data is a normal distribution and homogeneous so that it can be passed on the next data analysis by hypothesis test (t-test).

From the statistic calculations that have been done using MS Excel, a summary of t-test average value of pretest and posttest learning outcome can be seen in the following table 
TABLE I. RESULT OF DATA PROCESSING FOR T-TEST AVERAGE VALUE OF PRETEST AND POSTTEST LEARNING OUTCOME

\begin{tabular}{|c|c|c|}
\hline Statistic Data & Data pretest & Data Posttest \\
\hline Number of respondents & 28 students & 28 students \\
Average & 69.64 & 87.1 \\
Standard Deviation & 13.538 & 10.929 \\
Variance & 183.287 & 119.435 \\
\hline$t$ count & \multicolumn{2}{|c|}{5.3102} \\
$t$ table & \multicolumn{2}{|c|}{2.0049} \\
-value & \multicolumn{2}{|c|}{0.021166} \\
Significant level & 0.05 \\
\hline Information & \multicolumn{2}{|c|}{$\mathrm{t}$ count $>\mathrm{t}$ table or } \\
& $\mathrm{p}$-value $<$ of 0.05 \\
\hline
\end{tabular}

Based on data from above table, the results obtained $t$ count $=5.0049$ and $t$ table $(1-\alpha)(n 1+n 2-2)=2.0049$ so it can be stated that $\mathrm{t}$ count $>\mathrm{t}$ table. It means Ho rejected. Likewise, when viewed from the value of probability $(\mathrm{P}$ value $)=0.021166$ with significant level $(\alpha)$ level $=0.05$, so Pvalue has a significance level $(\alpha)$, which means Ho was rejected too. From the results of t-test, it can be concluded that the use of co-operative learning model PSG-type task-based of problem posing fraction material math takes effect on student learning outcomes.

Moreover, the cooperative learning model of PSG type is combined with the problem posing, so that the understanding of mathematics on the fraction material is increasing. In accordance with its position, problem posing is the first step of problem-solving. This has been disclosed by Leung \& Silver "research studies provided evidence that problem pos-ing has an influence on students' ability to solve word problem".

Student involvement in cooperative learning type TPSq based on the task of problem posing of fraction material math as a whole earn the average value of group activity of students from 3 meetings of learning amounted to 3.35 (84\%), with criteria of student activity level the overall is active.

For more details researcher recap average data and percentage of student activity each meeting above presented in the following table.

TABLE II. SUMMARY OF AVERAGE DATA AND PERCENTAGE OF STUDENT ACTIVITY FOR EACH MEETING

\begin{tabular}{|c|c|c|c|c|c|c|}
\hline \multirow{2}{*}{ Observer } & \multicolumn{2}{|c|}{$\begin{array}{c}\text { 1st } \\
\text { Meeting }\end{array}$} & \multicolumn{2}{c|}{$\begin{array}{c}\text { 2nd } \\
\text { Meeting }\end{array}$} & \multicolumn{2}{|c|}{$\begin{array}{c}\text { 3rd } \\
\text { Meeting }\end{array}$} \\
\cline { 2 - 7 } & \multicolumn{4}{|c|}{ Total average score / percentage (\%) } \\
\hline Observer I & 2.98 & $74.5 \%$ & 3.38 & $84.5 \%$ & 3.74 & $93.5 \%$ \\
\hline Observer II & 3.00 & $75 \%$ & 3.36 & $84 \%$ & 3.62 & $90.5 \%$ \\
\hline $\begin{array}{c}\text { Average } \\
\text { per meetings }\end{array}$ & 2.99 & 3.37 & 3.68 \\
\hline $\begin{array}{c}\text { Percentage } \\
\text { per meetings }\end{array}$ & $74.75 \%$ & $84.25 \%$ & $92 \%$ \\
\hline $\begin{array}{c}\text { Level of student } \\
\text { activity }\end{array}$ & Active & Active & $\begin{array}{c}\text { Very } \\
\text { active }\end{array}$ \\
\hline $\begin{array}{c}\text { Average of 3 } \\
\text { meetings }\end{array}$ & \multicolumn{5}{|c|}{3.35} \\
\hline $\begin{array}{c}\text { Percentage } \\
\text { 3 meetings }\end{array}$ & \multicolumn{5}{|c|}{$83.75 \%$} \\
\hline
\end{tabular}

For more details, the average group activity of students in percentage can be illustrated in the following chart.

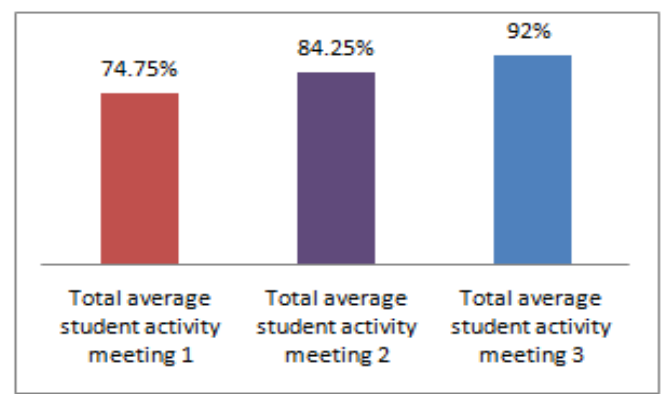

Figure 2. Chart Of The Average Percentage Of Total Students Activity

Slavin (2005:45) states that there are four elements of effective learning related to teacher activity which is known as QAIT model (Quality, Appropriateness, Incentive, Time) that is how well the delivery of knowledge or ability of teacher so that can help students easily to master material, the extent to which teachers master the material, how well teachers make sure students are motivated to do the task in a lesson, and how much time is given to the students to learn the material was taught.

TABLE III. SUMMARY OF AVERAGE DATA AND PERCENTAGE OF TEACHER ACTIVITY EACH MEETING

\begin{tabular}{|c|c|c|c|c|c|c|}
\hline \multirow{2}{*}{ Observer } & \multicolumn{2}{|c|}{$\begin{array}{c}1 \text { st } \\
\text { Meeting }\end{array}$} & \multicolumn{2}{c|}{$\begin{array}{c}\text { 2nd } \\
\text { Meeting }\end{array}$} & \multicolumn{2}{c|}{$\begin{array}{c}\text { 3rd } \\
\text { Meeting }\end{array}$} \\
\cline { 2 - 6 } Observer I & 3.44 & $86 \%$ & 3.78 & $94 \%$ & 3.78 & $94 \%$ \\
\hline Observer II & 3.26 & $81 \%$ & 3.52 & $88 \%$ & 3.81 & $95 \%$ \\
\hline $\begin{array}{c}\text { Average } \\
\text { per meeting }\end{array}$ & 3.35 & 3.65 & 3.80 \\
\hline $\begin{array}{c}\text { Percentage of } \\
\text { meeting }\end{array}$ & $84 \%$ & $91 \%$ & $95 \%$ \\
\hline $\begin{array}{c}\text { Level of } \\
\text { teacher ability }\end{array}$ & Good & Very good & Very good \\
\hline $\begin{array}{c}\text { an average of } \\
3 \text { meetings }\end{array}$ & \multicolumn{5}{|c|}{3.60} \\
\hline $\begin{array}{c}\text { Percentage of } \\
3 \text { meetings }\end{array}$ & \multicolumn{5}{|c|}{$90 \%$} \\
\hline
\end{tabular}

Conclusion: The average of 3 meeting is 3.60 or $90 \%$, the conclusion teacher is very good at managing the learning process. More details of the average total data or percentage of teacher activity each meeting above can be seen in the following chart.

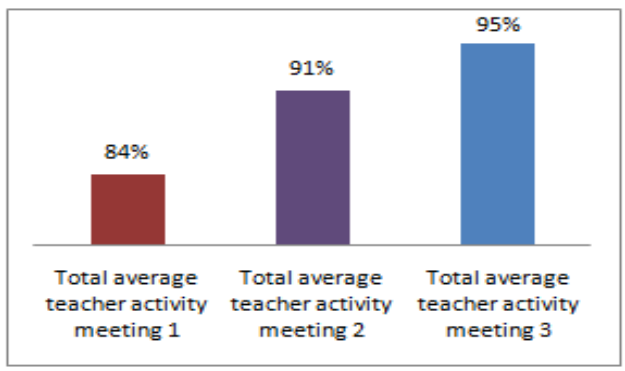

Figure 3. Chart Of The Average Percentage Of Total Teacher Activity 
Furthermore, questionnaire of students responses was done after completion of teaching material which consists of three meetings of learning and final test. From 8 questions responded by students regarding the learning aids, $84 \%$ stated agree or strongly agree, while from 26 questions regarding students' learning process, $85 \%$ states agree or strongly agree. Thus, the students' responses are positive.

Furthermore, the effectiveness of the learning model is based on the following aspects, i.e. learning completeness, student learning activity, teacher's ability to manage to learn, and student's response or interest to learning (referring to Slavin and Nieveen's opinion).

To answer the effectiveness of learning and referring from the opinions of experts, the following table presents these elements.

TABLE IV FOUR ELEMENTS OF LEARNING COMPLETENESS CRITERIA

\begin{tabular}{|c|c|c|c|c|}
\hline No & Aspects & Value & Criteria & $\begin{array}{l}\text { Conclusi } \\
\text { on }\end{array}$ \\
\hline 1 & $\begin{array}{c}\text { completeness of } \\
\text { learning }\end{array}$ & $\begin{array}{c}\text { There are } 23 \\
\text { students or } 82.14 \% \\
\text { greater or equal with } \\
\text { minimal mastery } \\
\text { criteria }(75)\end{array}$ & Complete & \multirow{4}{*}{ 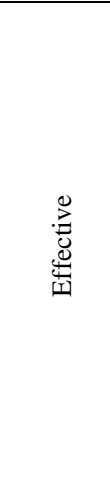 } \\
\hline 2 & $\begin{array}{c}\text { Teacher ability } \\
\text { to manage } \\
\text { classroom } \\
\text { activities } \\
\end{array}$ & $\begin{array}{c}\text { Average score of } \\
3.60 \text { or } 90 \%\end{array}$ & Very good & \\
\hline 3 & $\begin{array}{c}\text { Students } \\
\text { activity during } \\
\text { learning }\end{array}$ & $\begin{array}{c}\text { Average score of } \\
3.35 \text { or } 83.75 \%\end{array}$ & Active & \\
\hline 4 & $\begin{array}{l}\text { Students } \\
\text { response of } \\
\text { learning }\end{array}$ & $\begin{array}{c}85 \% \text { of } \\
\text { students agree or } \\
\text { strongly agree }\end{array}$ & Positive & \\
\hline
\end{tabular}

\section{CONCLUSION}

Based on the above explanation, it can be concluded that the use of cooperative learning model type TPSq-based with problem posing task on the topic of fraction implemented on the fourth-grade students of SDN Dr. Sutomo IX Surabaya take effect to the results of learning, the learning aids and process are effective, and the students' responses to the learning aids process are positive.

\section{REFERENCES}

[1] Adjie \& Maulana, 2006. Mathematical problem-solving. Ban-dung: UPI Press

[2] Anita Lie. 2010. Cooperative learning: mempraktekkan cooperative learning di Ruang-Ruang kelas. Jakarta: PT. Grasindo

[3] Arikunto, S., 2010. Research procedure: a practical approach. Jakarta: Rineka Cipta.

[4] Nieveen, N. 2006. Prototyping to Reach Product Quality. Design Approaches and Tools in Education and Train-ing . London: Kluwer Academic Publishers

[5] Silver, EA \& Cai, J. 200). Assessing students' mathematical problem posing: Teaching Children Mathematics, pp. 129-135

[6] Slameto. 2013. Learn and factors that influence it. Jakarta: Rineka Reserved

[7] Slavin, Robert E. 2005. Cooperative learning: theory, re-search and practice (N. Conan. Translations). Lon-don: Allymand Bacon. The original book was pub-lished in 2005

[8] Susanto, A. 2015. Theory of learning and teaching in primary schools. Jakarta : Prenadamedia

[9] Sudjana, Nana. 2010. Assessment results of the learning pro-cess. PT Remaja Rosdakarya. Bandung.

[10] Sugiyono. 2010. Qualitative and quantitative research meth-ods RND. Bandung: Alfabeta

[11] Law of the Republic of Indonesia Number 20 of 2003 on the System of National Education, (2003). Jakarta: Secre-tary of State of the Republic of Indonesia.

[12] Fleischer, K., \& Kin, K. (2014). U.S. Patent No. 8890889B1. Washington, DC: U.S. Patent and Trademark Office.

[13] AB O, A. B. An Introduction to statistics Twelve-Proportions and chi square Written by: Robin Beaumont e-mail: robin@ organplayers. co. uk Date last updated Tuesday, 27 April 2010.

[14] Buring, S. M., Bhushan, A., Broeseker, A., Conway, S., Duncan-Hewitt, W., Hansen, L., \& Westberg, S. (2009). Interprofessional education: definitions, student competencies, and guidelines for implementation. American journal of pharmaceutical education, 73(4), 59.

[15] Shaffer, J. P. (1995). Multiple hypothesis testing. Annual review of psychology, 46(1), 561-584. 